\title{
Teologiekroniek - 'n Kollega bekroon met die Andrew Murray-prys
}

J W Hofmeyr

(UP)

Groot was die nuus in die Fakulteit Teologie (Afd B) van die NG Kerk toe dit bekend geword het dat prof C J A (Cas) Vos die 1999 Andrew Murrayprys vir teologiese vakliteratuur ontvang het.

Die prys wat vanjaar vir die twintigste keer toegeken is, is die grootste prys in Afrikaans vir publikasies van dié aard. By 'n dinee op Dinsdagaand 4 Mei 1999 in 'n restaurant by die Staatsteater in Pretoria is die prys aan professor Vos oorhandig. Naas 'n erepenning en 'n oorkonde is 'n kontantbedrag van R10 000-00 ook aan hom oorhandig.

By hierdie glansgeleentheid is 'n Commendatio deur een van die beoordelaars vir die prys, professor J W (Hoffie) Hofmeyr uitgespreek. Dit word in sy geheel hier opgeneem.

\section{COMMENDATIO}

Dit is my besondere voorreg om namens vanjaar se drie beoordelaars van die Andrew Murrayprys vir teologiese vakliteratuur (proff J du Preez, P R van Dyk en ekself) 'n aanbeveling ten tye van die oorhandigingsgeleentheid uit te spreek.

Uiteraard sou dit vanaand ook besonder aangenaam gewees het om in die skadu van die Jonkershoekberge of Tafelberg (waar die naaswenners vandaan kom), so 'n spoggeleentheid by te woon, maar die voorloper van vanjaar, Cas Vos, laat aan ons geen keuse as om so 'n geleentheid vanaand in die skadu van Meintjieskop te vier nie.

Die Andrew Murrayprys het reeds in die twintig jaar van sy bestaan ' $n$ besondere aansien verkry. Die prys is tans sodanig gevestig dat dit saam met die Totius en Van Drimmelenpryse van die Suid-Afrikaanse Akademie as dié mees gesogte pryse vir Teologie beskou kan word. Vorige ontvangers van die Andrew Murrayprys is ondermeer Johan Heyns, Attie Barnard, Julian Müller, Willie Jonker, Ferdinand Deist en Wentzel van Huyssteen.

Om so 'n prys te ontvang beteken enersyds 'n bewys van erkenning en groot waardering vir gehaltewerk wat gelewer is en andersyds om te midde van strawwe kompetisie die hoogste sport te bereik. En dit is inderdaad die geval met Cas Vos se publikasie Die Volheid Daarvan (Vol 
I en II) ${ }^{1}$. Nie alleen was dit een van dertien inskrywings vir die prys nie maar dit verdien uiteindelik die erkenning wat dit toekom as 'n wetenskaplike, oorspronklike en gefundeerde stuk werk.

Dat Cas Vos 'n persoonlikheid met baie fasette is, kan nie betwyfel word nie. By hierdie geleentheid wil ek egter slegs fokus op hom as intellektueel, as skrywer en as mens. Cas Vos is eerstens 'n wetenskaplike, 'n intellektueel by uitstek. Om werklik te begryp wat ' $n$ intellektueel is, kan met vrymoedigheid by 'n baie bekende Suid-Afrikaner aangesluit word.

Dieselfde N P van Wyk Louw vir wie Cas Vos so lief is en soveel waardering het as die "groot skrywer/digter", omskryf die intellektueel in baie duidelike taal: “' $n$ Intellektueel is nie noodwendig, of veral, 'n geleerde of 'n hooggeleerde nie; hy hoef nie eers iemand te wees wat gestudeer het nie... die ware intellektueel (is) iemand wat dit vir hom tot lewensreël gemaak het om by elke saak redelik te dink, billik te oordeel, aarselend te veroordeel, en die eie mening met 'n bietjie nederige selfkritiek te beskou" 2 .

En so ken ons vir Cas Vos: alhoewel hy hooggeleerd is, is hy, om dit saam met Van Wyk Louw te sê, nie "bevooroordeeld soos 'n fanatikus, gretig om te oordeel en te veroordeel, en rotsvas oortuig dat die eie mening oor elke saak altyd en volledig die juiste is" nie. Cas Vos beskik oor die vermoë om sake op meriete te beskou, om die eie mening nie te oorspan nie, om 'n teëstander altyd beweegruimte te gun en om die eie mening altyd jaloers-krities te ondersoek.

Cas Vos is egter ook skrywer en woordkunstenaar by uitstek. In die skryf van die pryswennende boek was Vos eerstens intellektueel en wetenskaplike. Die Volheid Daarvan spreek van wetenskaplike rypheid en volheid, alhoewel nooit met arrogansie nie. Dit adem al die eise wat aan wetenskaplikheid gestel word. Daarbenewens is dit ook 'n nuwe en 'n selfstandige bydrae tot die groot saak van prediking wat die hartklop van die kerk en die gemeente behoort te wees. Alhoewel uitgebreide navorsing en leeswerk gedoen is, ontbreek dit nie by Vos aan eie oordeel nie. Verder is hierdie publikasie 'n relevante en aktuele bydrae tot die Teologie in die algemeen, maar ook tot die Praktiese Teologie in die besonder. Die feit dat Vos dit alles in besondere taal as woordkunstenaar giet, verhoog ook nog die waarde en skoonheid daarvan.

Ten slotte is Cas Vos ook mens onder mense. Cas verstaan heelwat van die lewe, beide van die vreugdes en die pyne daarvan. Hy weet van suksesse en hoogtepunte, maar hy ken ook van gesondheidsprobleme en terugslae. Sy styl saam met sy vrou en sy kinders is dié van klassieke 
eenvoud: die beeld wat hy uitstraal is die van entoesiasme en hoegenaamd nie van grootdoenerigheid nie. Uiteindelik kan met reg gesê word dat Cas Vos weet waaroor menswees gaan.

Hy vat dit self op 'n besondere manier saam in een van sy gedigte in sy onlangse verskene debuutbundel Vuurtong3. In die gedig $I$ korinthiers 13 sing hy 'n loflied op dié taal wat die essensie van die lewe uitmaak, naamlik die liefdestaal tot God en die liefdestaal tot die medemens.
"al dra die gode wit wolkpakke en sif soos reëndruppels neer, al sing visarende vir silwervisse liedere wat oor die vlei hangvlug, al wei beeste in hulle duisendtalle in dale en knip 'n uiltjie in krale, al dans jongmeisies met warm lywe vleesbevange mans se harte dronk, al roer 'n mens se faam oral tonge en pryk sy naam op almal se lippe, al pronk hy soos 'n skip op oseane en kan hy die see drooglê, is alles sonder dié taal 'n stom gebrabbel".

U sal met my saamstem dat Cas Vos, die intellektueel en wetenskaplike, die skrywer, die mens, vanjaar by uitnemendheid die Andrew Murrayprys vir teologiese vakliteratuur verdien. Daarvoor aan jou van harte geluk Cas, mag jy die vreugde van erkenning ten volle smaak, maar mag jy in dankbaarheid en in beskeidenheid en in toewyding jou pad verder bly loop.

\section{NOTAS:}

1 C J A Vos, Die Volheid daarvan I en II, Pretoria 1996.

2 P A Joubert (red), Gedagtes vir ons tyd: uit die prosa van N P van Wyk Louw, Kaapstad 1998, 37.

3 Cas Vos, Vuurtong, Pretoria 1999, 26. 